\title{
Language Shifts in Case of Language Policy of Kazakhstan
}

\author{
Zhainagul S. Beisenova \\ Kazakh University of the Humanities and Law, Astana, Kazakhstan \\ E-mail: zhaina_b@mail.ru
}

\section{Doi:10.5901/ajis.2013.v2n8p653}

\begin{abstract}
This paper contains the description and analysis of some aspects of language policy in the Republic of Kazakhstan. The description of the main trends of national programmes of functioning and development of all languages spoken in Kazakhstan. The attention is paid to the practice of non-stop language education that should ensure the high level of official language awareness by every citizen of the Republic and preservation of all the linguistic richness of Kazakhstani society. The regulations of the Language Act where the guarantee of protection and state support of all the languages spoken in the Republic are depicted in details in order to preserve the various ethnic cultures and languages within the territory, including the English. The descriptive characteristics of of language vitality of nations oft he country gives the opportunity to present the significance and importance of any language of Kazakhstani society. At the present the general conceptual basis oft he lanuage development in Kazakhstan is "National Programme of Language Functioning and Development: 2011-2020» [1], which is considered to be realized within 10 years. The main purpose oft he give programme is to extend and strengthen the social-communicative functions of the official language of the Republic, to preserve the general cultural functions of the Russian language, to develop the other languages spoken in Kazakhstan, to facilitate in the development of the English and other foreign languages. The cultural project of the country about language trinity is the new branch in language policy and finds the functional reflection in national standards of education of the country. Language education concepts reflect the world experience in the context of education, i.e. the acception of the unique national standardization on level structures and subject contents -6 levels of language awareness (Kazakh, Russian and foreign language) taking into account "General European Standards of Language Competence». In conclusion of the paper the results of the analysis of some aspects of language policy and national programme planning are presented.
\end{abstract}

Keywords: language situation; language policy; language development programmes; the official language; Russian; national languages; foreign languages; language vitality.

\section{Introduction}

Citizens of Kazakhstan celebrate the Day of Language every September. The consolidating idea of the celebration is the understanding of the essential value of each language and culture used in the country. In this multiethnic, multicultural and multilingual country as the Republic of Kazakhstan, the language policy is one of the fundamental aspects of language situation, defining as a measured system of conscientious influence to the development of language processes, extending the languages by spheres of social influence, presenting the part of political control on language situation and language conflicts. Language policy is realized in consequence with the Constitution of the Republic of Kazakhstan and Language Act, National programme of language functioning and development for 2011-2020. The project of National programme of language functioning and development for 2011-2020 is developed in consequence with the Constitution of the Republic of Kazakhstan (Article 7, 93), Law of the Republic of Kazakhstan «About Languages of the Republic of Kazakhstan» (from July 11, 1997), Decree of President of the Republic of Kazakhstan «About Statement of National Programmes List» (from March 19, 2010), and cultural project «Language Trinity» (Constitution of the Republic of Kazakhstan, 2002).

In accordance with the main purpose the prior objectives of Programme are the improvement and standardization of methodology of official language training; integration into all the spheres of life activity. According to independent experts' opinions President Nursultan Nazarbayev's support of the Kazakh language was extremely important in getting over the extension of bureaucracy: the Kazakh language «was also happy because of its being in an environment in which due to the Soviet time the notion of an ethnic group's coincidence with territory and language took root and found expression of Kazakhs being a unique nation with peculiar language and culture, and their language and culture are closely connected with their peculiar territory, i.e. Kazakhstan» (Fierman, 2005). 
The Law of the Republic of Kazakhstan, along with the announcement of the Kazakh language as official ensures the comprehensive protection and state support for all the languages spoken in the Republic, which is consistently reflected in the decision of the objectives of the programme as to provide the state support for preservation of other languages of Kazakhstan, providing the necessary conditions for language preservation and cultural enrichment of ethnic groups, the creation of conditions for the development of the languages of ethnic groups that form the linguistic diversity of Kazakhstani culture and the study of English and other foreign languages as a means of international communication of business: to provide the conditions necessary for the preservation of languages and the mutual enrichment of cultures of ethnic groups, expanding international cooperation in order to interact with the foreign language culture.

In this aspect, there is a set of problems related to the preservation of the level of the Russian language awareness as a competitive advantage of Kazakhstani citizens, preserving certain functions of the Russian language, the creation of favourable conditions for the study and preservation of the languages of ethnic groups living in Kazakhstan, promoting the study of English and other foreign languages.

\section{The Descriptive Characteristics of National Policy in the Kazakh Language Revival}

The programme, designed for ten years of implementation, is based on an analysis of the language construction in the country, and takes into account the views and recommendations of the expert community, dealing with the language issues. Past wave of adoption of the law on languages in 90s, (1997-2000: Law «On languages» National programme of language functioning and development for 1998-2000, 2001-2010: National programme of language functioning and development, forming the legal basis of language construction in main areas of public life), the strategy of language construction, which determined the proclamation of the Kazakh language as official, currently led to the conclusion that giving the country's language is not enough. Scientists have raised the issue of the real ways and opportunities to expand the social functions of the Kazakh language, in order to function as an official language of the state. Due to the current estimation of language situations and analysis of the results of the implementation of laws into life, all aspects of the programme, based on the priority of the development of the official language as the most important factor in strengthening national unity and designed to meet the spiritual, cultural and linguistic needs of the citizens, which is reflected in such areas of the programme: the development and implementation of the Kazakh language teaching through a model of non-stop language education, the creation of a network of accredited teaching centres of the official language teaching, the creation of a system to promote the process of teaching the official language. All of them suggest that the vitality of the Kazakh language as a problem loses its topicality. One of the main factors determining the language vitality is called as a language proficiency by its native speakers (Stewart, 1962), the number of social functions of language and thus its application in the most important areas of social life (MacKonnel, 2000), and ethnic self-awareness (Mihalchenko, 1992).

In accordance with the above mentioned facts, we focus only on some of the important features and results of the main branches of new language policy of Kazakhstan.

Legal regulation of the functional status of the official language was a logical start to improve the language situation. Multi-subject nature of the language acts govern the order for the Russian language and the languages of other ethnic groups and languages. The main change in the status of the official, the Kazakh language is a clear definition of the conditions for the implementation of the language of the main nationality that was previously the privilege of the Russian language.

One of the clear indicators of the social and political language policy in the field of national programmes to support the Kazakh language is the new project «Language Trinity» as the basis of the national standard of language teaching in the country. In modern universities of Kazakhstan the study of three languages are implemented: the official (Kazakh), Russian and foreign. Conceptual framework for the implementation of the cultural project «Language Trinity» provides «The Concept of Foreign Language Education», «The Concept of Language Education of the Republic of Kazakhstan», providing the experience of standardization and ranking levels of training on the integrated models of 2 European standards. Thus, a single, unified educational and linguistic, social and cultural space. System of centralized management of a language education is coordinated on all trinity languages to assist: 1) the preservation of the Russian language; 2) the preservation and development of the languages of ethnic groups living in Kazakhstan; 3) the study of English and other foreign languages as a means of business cooperation.

Development and implementation of Kazakh language teaching through a model of non-stop education is reflected in the new national teaching standard of the education system. The Kazakh language is introduced at the elementary level and continues into middle and senior levels of secondary schools of the country. Then teaching the official language 
goes on in higher education. Students continue improving their knowledge of language within one or more courses in the amount of six credits of optional courses and elective courses. In the framework of the National programme of language functioning and development a national cultural project «Language Trinity (Kazakh, Russian and the foreign language)» has started (2011), in which the rules for the content of training bachelors with the amount of credit hours on the Kazakh language are established, Table 1.

Table 1. The Kazakh Language Awareness Standard by Levels

\begin{tabular}{|c|c|c|c|c|c|}
\hline $\begin{array}{l}\text { European } \\
\text { Levels od } \\
\text { Language } \\
\text { Competence }\end{array}$ & $\begin{array}{c}\text { National } \\
\text { Standards of } \\
\text { European } \\
\text { Language } \\
\text { Awareness } \\
\text { Levels }\end{array}$ & $\begin{array}{l}\text { Modelling Speech } \\
\text { Types and } \\
\text { Communication } \\
\text { Forms }\end{array}$ & $\begin{array}{c}\text { Descriptives } \\
\text { (characteristics) of } \\
\text { Levels }\end{array}$ & Assessment Criteria & $\begin{array}{l}\text { Assessment } \\
\text { System }\end{array}$ \\
\hline A1 & $\begin{array}{l}\text { Level of liminal } \\
\text { sufficiency }\end{array}$ & Liminal methodology & $\begin{array}{l}\text { Liminal awareness of } \\
\text { language information }\end{array}$ & $\begin{array}{l}\text { Realization of } \\
\text { communicative intention }\end{array}$ & $\begin{array}{l}\text { Note in the } \\
\text { transcript of } \\
\text { diploma about } \\
\text { achieved level }\end{array}$ \\
\hline $\mathrm{A} 2$ & $\begin{array}{l}\text { Level of liminal } \\
\text { sufficiency }\end{array}$ & & & $\begin{array}{l}\text { Consequence with lingual } \\
\text { and cultural norms of } \\
\text { native speakers }\end{array}$ & $\begin{array}{l}\text { Note in the } \\
\text { transcript of } \\
\text { diploma about } \\
\text { achieved level }\end{array}$ \\
\hline B1 & $\begin{array}{l}\text { Level of } \\
\text { foundation } \\
\text { sufficiency }\end{array}$ & \begin{tabular}{|ll} 
1. & $\begin{array}{l}\text { Dialogue - } \\
\text { questioning; }\end{array}$ \\
2. & Dialogue - \\
& opinion \\
exchanges \\
3. & Dialogue - \\
& conversation
\end{tabular} & $\begin{array}{l}\text { - system of language } \\
\text { awareness; } \\
\text { - system of speech and } \\
\text { communication awareness } \\
\end{array}$ & $\begin{array}{l}\text { Realization of } \\
\text { communicative intention; } \\
\text { Logical structural } \\
\text { integrity; } \\
\text { Possession of subject } \\
\text { content of the speech. }\end{array}$ & $\begin{array}{l}\text { Note in the } \\
\text { transcript of } \\
\text { diploma about } \\
\text { achieved level }\end{array}$ \\
\hline B2 & $\begin{array}{l}\text { Level of } \\
\text { foundation } \\
\text { standards }\end{array}$ & $\begin{array}{l}\text { Conversation, } \\
\text { interview, discussion. } \\
\text { Types of oral and } \\
\text { written communication: } \\
\text { writing, narration, } \\
\text { reasoning, message }\end{array}$ & $\begin{array}{l}\text { - system of language } \\
\text { awareness and means to } \\
\text { apply the intercultural, } \\
\text { communicative activity; } \\
\text {-система речи и } \\
\text { коммуникации }\end{array}$ & $\begin{array}{l}\text { Realization of } \\
\text { communicative intention; } \\
\text { Logical structural } \\
\text { integrity; } \\
\text { Possession of subject } \\
\text { content of the speech; } \\
\text { Compliance with lingual } \\
\text { and cultural norms of } \\
\text { native speakers; } \\
\text { Linguistic speech } \\
\text { correctness, possession } \\
\text { metalanguage. }\end{array}$ & $\begin{array}{l}\text { Note in the } \\
\text { transcript of } \\
\text { diploma about } \\
\text { achieved level }\end{array}$ \\
\hline C1 & $\begin{array}{l}\text { Level of upper } \\
\text { foundation } \\
\text { standards }\end{array}$ & $\begin{array}{l}\text { Forms of } \\
\text { communication: } \\
\text { 1. Interview. } \\
\text { 2. Discussion. } \\
\text { 3. Dispute }\end{array}$ & $\begin{array}{l}\text { Readiness and ability to } \\
\text { realize the following } \\
\text { communicative acts: } \\
\text { - vocabulary choice } \\
\text { spontaneously, without } \\
\text { difficulties, to express the } \\
\text { opinion; fluent speaking on } \\
\text { various academic and } \\
\text { professional fields; } \\
\text { - to express opinions } \\
\text { fluently. }\end{array}$ & $\begin{array}{l}\text { Realization of } \\
\text { communicative intention; } \\
\text { Logical structural } \\
\text { integrity; } \\
\text { Possession of subject } \\
\text { content of the speech. } \\
\text { Compliance with lingual } \\
\text { and cultural norms of } \\
\text { native speakers }\end{array}$ & $\begin{array}{l}\text { Certificate of } \\
\text { confirmation } \\
\text { about achieved } \\
\text { level of elective } \\
\text { course }\end{array}$ \\
\hline
\end{tabular}

The above mentioned requirements and rules are aimed at developing intercultural communicative competence of students of various fields of university education at the basic standard level.

There are other various vital signs of the Kazakh language: ethnic and cultural, social and demographic, social and 
functionl (Suleimenova, Shaimerdenova, 2007). It is impossible not to recognize the positive role of national programmes in social and cultural aspects, for national education spheres, spiritual culture, mass communication. In this case, the main factors are the linguistic unity of the people of the media and education, factors that contribute to the inclusion of all social layers and large territorial spaces. Therefore, we must recognize the current solution to this problem in the formulation of such a goal in the programme as enhancing the prestige of the official language with the following results: creation of the Centre of creative solutions to promote the official language, the amount of material in the media to promote a positive image of the native speakers of the official language, the number of socially important projects aimed at addressing the problems of promoting the official language, the share of Kazakh-speaking content in the media, the creation of TV channels broadcasting in the official language, the proportion of products supporting the use of the official language in information technologies.

\section{Descriptive characteristics of national policy of further development of the Russian language as interethnic communication}

Today, the whole world knows that the collapse of the Soviet Union, the emergence of new independent states, one of which is Kazakhstan, and many other issues have changed the Russian communicative and linguistic space. The functioning space of the Russian language as an international, educational institutions become less used, it became the subject of an optional study of school and university programmes. Therefore the problem of the Russian language vitality was the subject of consideration in connection with the new language policy in Kazakhstan. Status of the Russian language in Kazakhstan is defined as the status of the language of interethnic communication (Constitution of the Republic of Kazakhstan, 1995). Russian is used officially along with the Kazakh language in state bodies (Language Act, 1997, Article 5). Today in Kazakhstan, the Russian language is considered to be the linguistic stock of Kazakhstani linguistic community, and the economic factors and the economic lift for economic cooperation between the peoples of the $\mathrm{CIS}$ countries. Preservation of the Russian language in communicative and linguistic space determines the direction of the fourth goal of the linguistic stock of Kazakhstan, which involves the organization of the working system of functioning the Russian language. The further teaching and intellectual support system of teaching the Russian language are the followings:

- formation of the new distance education programmes, educational materials, electronic textbooks, and training equipments;

- improvement of the quality of the Russian language teaching in ethnic schools by implementation of innovative methods of the Russian language schooling;

- creation of the Russian language courses and training centres for repatriates, foreigners and other social groups;

- constant monitoring of the educational standards, curricula, textbooks and teaching aids with the assistance of the expert community.

According to the well-known Kazakhstani scientists the satisfaction of language rights and claims of Russian speaking Kazakhstani citizens is the effective political measure directed to prevent the language and ethnic conflicts. (Suleimenova, Smagulova, 2005)

\section{Descriptive characteristics of national policy for creating the favourable conditions to study and preserve the ethnic languages spoken in Kazakhstan}

The great majority of languages of ethnic groups in Kazakhstan is the language of immigrants or deport nations having historic country of residence. These ethnic groups' languages can be divided into three groups: Exogenous (Trudgill, 2003) - Abkhaz, Azerbaijani, Belorussian, Russian, Ingush, Karakalpak, Kyrgyz, Korean, Latvian, German, Polish, Tartar, Eastern Turki, Ukrainian and others. Endogenous (Trudgill, 2003) - Dungan, Karelian, Crimean Tatar, Selkup, Meskhetian, Udihe and others. The following objectives as ensuring the requirements to preserve languages and mutual enrich cultures of ethnos are set in the Programme:

- involvement of experienced teachers, native speakers, the use of international practice and high technology in teaching of native language;

- creating the conditions for education in secondary schools, language centres, Sabbath schools, national revival schools of ethnos representatives in Kazakhstan;

- ensuring the necessary conditions for language preservation and mutual enrichment of ethnos cultures; 
- ensuring the preservation of historic and modern written heritage of ethnic groups (records, libraries, researches).

Humanitarian Universities graduate specialists on German, Polish, Eastern Turki, Turkish, Korean languages in Kazakhstan, but it should be noted that the number of students is few. The National programme supports the expat communities in publication of newspapers and magazines. For example, "Deutsche Algemaine Zeitung" (newspaper of German expat community), "Кору ильбо" (newspaper of Korean expat community), "Уйгур авази" (newspaper of Uigur expat community), "Украінскі новини" (newspaper of Ukrainian expat community). The unique phenomenon in the national policy on peacekeeping and interethnic concord in Kazakhstan is the creation of the Assembly of people of Kazakhstan (1995), which authorized to engage in problem solving the national policy at the government level.

One cannot ignore the fact that apart from the languages of expat communities there are groups of immigrant languages (they are outside of the strategy of language planning), representatives of the people who have recently settled in the country for temporary residence. These are English, German, Chinese, Hindi, Urdu and other languages. It is necessary to notice the good knowledge of the official language by the representatives of these languages that emphasize their loyalty to language policy of the country.

\section{Descriptive characteristics of national policy to promote learning the English and other foreign languages}

Learning English and other foreign languages is the another priority of National programme on developing the languages. In this regard, the following ways of achievements and measurements are determined:

- expansion of international cooperation in order to interact with foreign language cultures;

- providing educational materials for team and individual studies;

- revision of curricula;

- reinforcement of requirements for the system and process of teaching at the universities and colleges training the future teachers of foreign languages;

- teacher training on natural science and mathematics in English;

- promotion of cooperation to share experiences and involvement of native speaker teachers;

- accessibility of language practice for students and teachers of schools and universities in foreign countries; carrying out the muss cultural events under the intergovernmental agreements (Culture days of foreign countries, exhibitions, the screening of feature and documental films).

In the development of English as a business language in aid of the integration into the global economy in the context of education the common national standardization on the level structure and subject contents is adopted - 6 level of proficiency and second language skills taking into account the national circumstances of "Pan-European standards of language competency" [12]. LAP and LSP language programs, B1 and B2 levels, LSP course are adopted in professional training of students in non-language universities. Industrial non-language universities train specialists who have a good command of a foreign language as a means of establishment of the scientific and cultural contacts with the native speakers, and the tool of professional communication for successive shared experience in the future work activity, Table 2. (A Common European Framework of Reference for Languages Learning, Teaching, Assessment, 1986) 
Table 2. The Standard Level of Foreign Language Teaching in Humanitarian Universities

\begin{tabular}{|c|c|c|c|c|c|}
\hline $\begin{array}{l}\text { European } \\
\text { Levels od } \\
\text { Language } \\
\text { Competence }\end{array}$ & $\begin{array}{c}\text { National } \\
\text { Standards of } \\
\text { European } \\
\text { Language } \\
\text { Awareness } \\
\text { Levels }\end{array}$ & $\begin{array}{c}\text { Modelling Speech Types } \\
\text { and Communication } \\
\text { Forms }\end{array}$ & $\begin{array}{c}\text { Descriptives } \\
\text { (characteristics) of } \\
\text { Levels }\end{array}$ & Assessment Criteria & $\begin{array}{c}\text { Assessment } \\
\text { System }\end{array}$ \\
\hline B1 & $\begin{array}{l}\text { Level of liminal } \\
\text { sufficiency }\end{array}$ & $\begin{array}{l}\text { Dialogue-questions; } \\
\text { dialogue - discussion; } \\
\text { dialogue-conversation } \\
\text { Types of oral and written } \\
\text { communication: } \\
\text { Types of written speech } \\
\text { products: } \\
\text { e-mail message of a private } \\
\text { nature, } \\
\text { text, message, } \\
\text { exposition, } \\
\text { autobiography, CV }\end{array}$ & $\begin{array}{l}\text { Acquiring the language } \\
\text { system and methods of } \\
\text { its use in intercultural } \\
\text { communication } \\
\text { activities; keeping up the } \\
\text { talk or discussion: } \\
\text { - the ability of holding } \\
\text { partner's attention } \\
\text { during the dialog; show } \\
\text { interest; } \\
\text { in monologue speech: }\end{array}$ & $\begin{array}{l}\text { Realization of } \\
\text { communicative } \\
\text { intention; } \\
\text { Logical structural } \\
\text { integrity; } \\
\text { Possession of } \\
\text { subject content of the } \\
\text { speech. } \\
\text { Compliance with } \\
\text { lingual and cultural } \\
\text { norms of native } \\
\text { speakers; } \\
\text { Linguistic speech } \\
\text { correctness; } \\
\text { possession } \\
\text { metalanguage. }\end{array}$ & $\begin{array}{l}\text { Note in the } \\
\text { transcript of } \\
\text { diploma about } \\
\text { achieved level }\end{array}$ \\
\hline B2 & $\begin{array}{l}\text { Level of liminal } \\
\text { standards }\end{array}$ & $\begin{array}{l}\text { Conversation, interview, } \\
\text { discussion. } \\
\text { Types of oral and written } \\
\text { communication. } \\
\text { Types of speech acts:. } \\
\text { Types of written speech } \\
\text { products CV, fax, official } \\
\text { letter, abstracts, essay. }\end{array}$ & $\begin{array}{l}\text { Acquiring the language } \\
\text { system and its methods } \\
\text { of use in intercultural } \\
\text { communication } \\
\text { activities; } \\
\text { - system of speech and } \\
\text { communication to carry } \\
\text { on a dialogue fluently } \\
\text { and off hand in oral and } \\
\text { written form }\end{array}$ & $\begin{array}{l}\text { Realization of } \\
\text { communicative } \\
\text { intention; } \\
\text { Logical structural } \\
\text { integrity; Possession } \\
\text { of subject content of } \\
\text { the speech. } \\
\text { Compliance with } \\
\text { linguocultural norms } \\
\text { of native speakers } \\
\text { Linguistic speech } \\
\text { correctness; } \\
\end{array}$ & $\begin{array}{l}\text { Note in the } \\
\text { transcript of } \\
\text { diploma about } \\
\text { achieved level }\end{array}$ \\
\hline
\end{tabular}

\section{Conclusion. Efficiency Results of Language Policy}

The present day we confidently may say that the process of the language policy in the Republic of Kazakhstan is successful. In Soviet times the language planning in Kazakhstan did not exist. There was the official Soviet language policy aimed at reducing the communicative Kazakh-speaking world and steady growth of Kazakh-Russian bilingualism. At present time there is a dramatic expansion of the functioning spheres and the structure modernization of the Kazakh language. Russian-Kazakh bilingualism is being formed. The main reasons of such positive process are political and economical stability in the society, improvement of social and economic situation in the country, the right strategy of the tools in language policy, education and others. According to the research in 1990-91,32.35\% of students were taught in Kazakh while more than $65 \%$ of students in Russian. Nowadays the situation is opposite: 62.5 percent of students in Kazakh and 33.5 percent in Russian. Herewith the number of schools with the languages of national groups (Eastern Turkic, Tadjik, Turkish, Ukrainian) have increased. There are six English schools in the country. $46.8 \%$ of the students are taught in Russian, $51.6 \%$ in Kazakh which is four times more than in the first year of the country independence. (Altynbekova, 2011)

Director of the Study Center of Central Asia and Kazakhstan, University of Seattle, (USA) William Fierman estimated the idea as a right one at the international academic conference "Multilingualism: language - conscious culture" in Almaty: "In my opinion that idea is correct and will contribute to the development of the country". (Fierman, 2008)

The main factor of language policy, as it turned out, is the population process. After the 1999 census the increase of Turkish-speaking population in the country was observed due to the rise of birthrate and the growth of young 
population. According interim results of the 2009 census Kazakh people are about $67 \%$ of the population (over 10 million). (Seisenbekova, 2011) "Ultimately the most powerful factor in determining the language policy is demography. For example, the Russian language has retained its importance in Kazakhstan. However, the present demographic trends give a reason to believe that over time its value will be reduced. "If you speak only in one language in Kazakhstan, preferable choice for you will be Russian in most spheres. However the situation is changing and changing very seriously". (Fierman, 2008)

The idea of recognition the Kazakh language as the official language can be the basis of Kazakhstani patriotism and national idea which is necessary for the cohesiveness of Kazakh people as a nation. Kazakhstan is one of the few countries which resolved problems of the language policy without heated conflicts and convulsions. There are conditions for the free development of ethnos languages in Kazakhstan. The government fully supports this process. (Kuzakov, 2007)

\section{References}

Фиерман У. (2005), Элиты и алфравиты. Поворот языкового сдвига в Казахстане // Этнографическое обозрение - Москва, №6, c.49-71.

Stewart W. (1962), An outline of linguistic typology for describing multilingualism. "Study of the role of second languages in Asia, Africa and Latin America, Washington,

Белл Р.Т. (1980), Социолингвистика. Цели, методы и проблемы - М.

МакКоннел Г.Д. (2000), Предисловие. Письменные языки мира: Языки Российской Федерации. Социолингвистическая энциклопедия. Книга 1 - Москва.

Михальченко В.Ю. (1992), Законы о языках: процессы реализации // Русский язык в СНГ.- Москва, № 1-3

Сулейменова Э.Д., Шаймерденова Н.Ж. (2007), Языки народов Казахстана. Социолингвистический справочник. - Астана.

Сулейменова Э.Д., Смагулова Ж.С. (2005), Языковая ситуация и языковое планирование в Казахстане.- Алматы.

Trudgill P. (2003), Glossary of Social Linguistics, Edinburgh University press.

Сейсенбекова Ж. (2011), Дискуссия о госязыке отвлекает казахстанцев от социально-политических проблем: http://www.alternativakz.com/index.php?nid=66

Фиерман У. (2008), Идея триединства языков в Казахстане правильна и будет способствовать развитию страны - мнение американского ученого: http://www.zakon.kz/111622-ideja-triedinstva-jazykov-v-kazakhstane.html.

Вайц Р. (2008), Центральная Азия: взгляд на языковую политику: http://www.spik.kz/?id=104\&lan=ru\&pub=782

Кузаков М. (2007), Триединство языковой политики: http://megapolis.kz/art/Triedinstvo_yazikovoy_politiki

A Common European Framework of Reference for Languages Learning, Teaching, Assessment (1986), Strasbourg

Государственная программа функционирования и развития языков на 2001-2010 годы (2001) // Казахстанская правда. Астана

Закон Республики Казахстан «О языках в Республике Казахстан» (1997)

Конституция Республики Казахстан $(2002),(1993,1995)$

Культурный проект «Триединство языков (казахский, русский и иностранный языки)», 2011

Проект Государственной программы функционирования и развития языков на 2011 - 2020 годы (2011), Астана

Указ Президента Республики Казахстан «Об утверждении перечня государственных программ» (от 19 марта 2010)

Языковая политика Республики Казахстан. Сборник документов. - Астана 2002 